\title{
Modelling Natural Radioactivity in Sand Beaches of Guarapari, Espírito Santo State, Brazil
}

\author{
Danilo C. Vasconcelos ${ }^{1}$, Patricia A. L. Reis ${ }^{1}$, Claubia Pereira ${ }^{1}$, Arno H. Oliveira ${ }^{1}$, \\ Talita O. Santos ${ }^{1}$, Zildete Rocha ${ }^{2}$ \\ ${ }^{1}$ Departamento de Engenharia Nuclear, Escola de Engenharia Universidade Federal de Minas Gerais, Belo Horizonte, Brasil \\ ${ }^{2}$ Centro de Desenvolvimento da Tecnologia Nuclear/Comissão Nacional de Energia Nuclear (CDTN/CNEN), Laboratório de Trítio, \\ Belo Horizonte, Brasil \\ Email: claubia@nuclear.ufmg.br, rochaz@cdtn.br
}

Received December 8, 2012; revised February 11, 2013; accepted March 4, 2013

Copyright (C) 2013 Danilo C. Vasconcelos et al. This is an open access article distributed under the Creative Commons Attribution License, which permits unrestricted use, distribution, and reproduction in any medium, provided the original work is properly cited.

\begin{abstract}
Using gamma-ray spectrometry, the activity concentration of naturally occurring radionuclides ${ }^{226} \mathrm{Ra},{ }^{212} \mathrm{~Pb},{ }^{214} \mathrm{~Pb},{ }^{232} \mathrm{Th}$, and ${ }^{40} \mathrm{~K}$ was determined in sand beaches samples from different areas in Guarapari, Espírito Santo state, from Brazil. The absorbed dose rates and annual effective dose were calculated and the results were compared with the internationally accepted values as well as others high background radiation areas (HBRAs). The activity concentration of the ${ }^{232} \mathrm{Th}$ in Areia Preta as well as the absorbed dose rates and annual effective dose were higher than the others regions compared. The results show that Areia Preta in Guarapari has higher background found in beaches in world. This work is part of a research project for the natural background determination of the Brazilian coast.
\end{abstract}

Keywords: Gamma-Ray Spectrometry; Beach Sand; Guarapari

\section{Introduction}

People are exposed to ionizing radiation from naturally occurring radionuclides that there are in the earth's environmental. Radionuclides in soils, belonging to ${ }^{232} \mathrm{Th}$, ${ }^{235} \mathrm{U}$ and ${ }^{238} \mathrm{U}$ series as well as radioisotope of potassium $\left({ }^{40} \mathrm{~K}\right)$ are the major contributors of outdoor terrestrial natural radiation [1]. These radionuclides are not uniformly distributed, their concentration depends upon the local geology of each region in the world [2]. Although their presence result in a relatively small amount of radiation dose, in some regions known for high background radiation levels (HBRA) [3], the knowledge of their distribution in soil, sand and rock plays an important role in radiation protection and measurement [2]. Ramsar, Iran [4], due to the concentration of ${ }^{226} \mathrm{Ra}$ and daughters which are brought to Earth's surface by hot springs, and Orissa and Kerala, India [5], due to the monazite sands, are examples of HBRA. In certain beaches of Brazil, there are areas known for their high background radiation, which geological and geochemical characteristics increase the levels of natural radiation [3]. Monazite sand is the main source of the high background from Atlantic coast from Brazil and it contributes to increase the envi- ronmental dose. The more important area begins below Guarapari, Espírito Santo, going up Porto Seguro, Bahia (Figure 1), and it is formed by pre-Cambrian rocks and Tertiary and Quarternary deposits. In 2009, the Departamento de Engenharia Nuclear (DEN)/Universidade Federal de Minas Gerais (UFMG) and Centro de Desenvolvimento da Tecnologia Nuclear (CDTN)/Comissão Nacional de Energia Nuclear (CNEN) began a research to determine reference levels of this region using gamma spectrometry. The first part of this research analysed beach sands from the extreme south of Bahia state, between Porto Seguro and Caravelas (Figure 1) [6]. The results showed Cumuruxatiba as HBRA region. Continuing in the south direction, Guarapari is a region cited by some studies $[2,7,8]$ by its high environmental radiation. In this work, the same methodology as used in $\mathrm{Cu}-$ muruxatiba was applied to evaluate the Guarapari area. The gamma-ray activity of radioisotopes such as ${ }^{232} \mathrm{Th}$, ${ }^{226} \mathrm{Ra}$, and ${ }^{40} \mathrm{~K}$, in beach sand samples from Guarapari was measured and the absorbed dose rate and the effective dose rates were calculated and compared with internationally accepted values as well as others HBRAs. The goal is validate the measurement methodology comparing the results obtained in this work with data referenced 


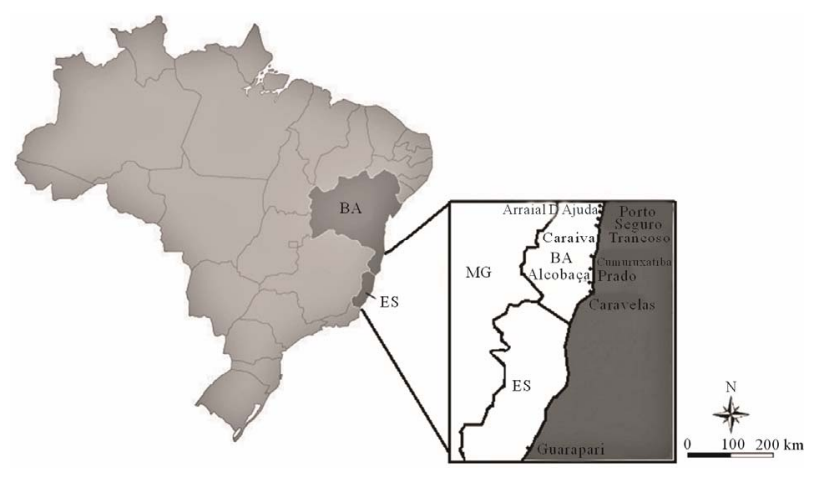

Figure 1. Geographic localization of the extreme south of Bahia state and of the Guarapari city from Espírito Santo State (modified from [11,12]).

in some studies.

\section{Material and Methods}

Beach sand samples were collected in Areia Preta, Praia do Morro and Setiba in Guarapari city, Espírito Santo state, in January 2010. The samples were collected from about $10 \mathrm{~cm}$ deep. Each sample was collected from an area corresponding to $1 \mathrm{~m}^{2}$ and were homogenized in situ. This sand mixture, weighing approximately $1.5 \mathrm{~kg}$, was considered representative of the profile, as done by [9]. For each local, twelve samples have been measured. The samples were dried for about 48 hours in an oven at $60^{\circ} \mathrm{C}$. The analytical technique used for the gamma emitters isotopes ${ }^{214} \mathrm{Bi}\left({ }^{226} \mathrm{Ra}\right),{ }^{228} \mathrm{Ac}\left({ }^{232} \mathrm{Th}\right)$ and ${ }^{40} \mathrm{~K}$ was gammaray spectrometry. Table 1 shows the radionuclides, the specific gamma-ray line used and the detection limits that were calculated according to procedures and experimental conditions [10].

\subsection{Gamma-Ray Spectrometry}

The specific activities of the radionuclides ${ }^{226} \mathrm{Ra}$ and ${ }^{40} \mathrm{~K}$ in the collected samples are determined in a specially reduced background detection system, consisting of a hyper-pure germanium detector (HPGe), coaxial geometry, $15 \%$ relative efficiency. The data are treated with Genie 2000 software. The efficiency and energy curves for calibrations are determined using internationally certificate standard solution prepared by PNI/IRD/CDTN (Programa Nacional de Intercomparação/Instituto de Radioproteção e Dosimetria/Centro de Desenvolvimento da Tecnologia Nuclear). The samples, after being dried and weighed, are transferred to Marinelli beakers (500 $\mathrm{mL}$ ). Each sample is hermetically and carefully sealed to prevent the escape of gaseous ${ }^{222} \mathrm{Rn}$ and ${ }^{220} \mathrm{Rn}$. It is kept aside for 30 days to reach radioactive equilibrium of the ${ }^{226} \mathrm{Ra}$ between ${ }^{214} \mathrm{~Pb}$ and ${ }^{214} \mathrm{Bi}$ radon's daughters. In ${ }^{232} \mathrm{Th}$ decay chain the radioactive equilibrium of ${ }^{232} \mathrm{Th}$ between ${ }^{228} \mathrm{Ra}$ and ${ }^{212} \mathrm{~Pb}$ is easily reached due the short half-life of
Table 1. Gamma-ray lines and detection limits for the radionuclides.

\begin{tabular}{|c|c|c|}
\hline Radionuclide & $\begin{array}{l}\text { Used gamma-ray lines } \\
\text { [energy (keV)—emission } \\
\text { probability] }[13,14]\end{array}$ & $\begin{array}{l}\text { Detection limit } \\
\quad\left(\mathrm{Bq} \cdot \mathrm{kg}^{-1}\right)^{\mathrm{a}}\end{array}$ \\
\hline${ }^{40} \mathrm{~K}$ & $1460.8(10.7 \%)$ & 0.5 \\
\hline${ }^{214} \mathrm{Bi}\left({ }^{226} \mathrm{Ra}\right)^{\mathrm{b}}$ & $609.3(46.3 \%)$ & 0.2 \\
\hline${ }^{228} \mathrm{Ac}\left({ }^{232} \mathrm{Th}\right){ }^{\mathrm{b}}$ & $\begin{array}{c}338.3(11.4 \%) ; 911.6(27.7 \%) \\
968.2(16.6 \%)\end{array}$ & 0.2 \\
\hline${ }^{224} \mathrm{Ra}\left({ }^{212} \mathrm{~Pb}\right)$ & $238.6(44.6 \%)$ & 0.2 \\
\hline${ }^{214} \mathrm{~Pb}$ & $\begin{array}{c}241.9(7.43 \%) ; 295.2(19.3 \%) \\
351.9(37.6 \%)\end{array}$ & 0.2 \\
\hline
\end{tabular}

${ }^{\mathrm{a}}$ The detection limit is given by the equation $\mathrm{LD}=2.71+4.65 \delta$ for $95 \%$ confidence limit, where $\delta$ is the standard deviation of the background in the

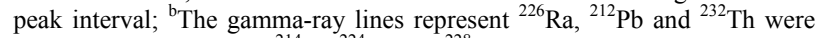
determined indirectly by ${ }^{214} \mathrm{Bi},{ }^{224} \mathrm{Ra}$ and ${ }^{228} \mathrm{Ac}$ respectively.

the decay products of ${ }^{228} \mathrm{Th}$. In environment, ${ }^{226} \mathrm{Ra}$ is in equilibrium with ${ }^{238} \mathrm{U}$ and ${ }^{228} \mathrm{Ra}$ is in equilibrium with ${ }^{232} \mathrm{Th}$ only if no occur leaching ${ }^{226} \mathrm{Ra},{ }^{228} \mathrm{Ra}$ and its parents. After, all samples are submitted to gamma-ray spectrometry. The samples are counted for 24 hours in order to obtain statistically small uncertainty for the gamma-ray peak of interest.

Following the spectrum analysis, count rates for each detected photo peak and activity concentration in units of Becquerel per kilogram for each nuclide are calculated based on the Equation (1):

$$
A_{E i}=N_{E i} / m \varepsilon_{E i} t \gamma_{E i}
$$

where $N_{E i}$ is the net peak area at energy $E_{i}$ of radionuclide $i$; $t$ the counting time in seconds; $m$ is the mass of samples in $\mathrm{kg} ; \varepsilon_{E i}$ and $\gamma_{E i}$ are detection efficiency and emission probability of gamma-ray, respectively.

\subsection{Calibration}

Energy calibration was performed in the energy range using point sources from 0.1 to $2 \mathrm{MeV}$ made by Institute of Isotopes Co., Ltd., Budapest, Hungary. The following photon emissions and radionuclides were used: ${ }^{241} \mathrm{Am}$, ${ }^{133} \mathrm{Ba},{ }^{152} \mathrm{Eu},{ }^{109} \mathrm{Cd}$ and ${ }^{60} \mathrm{Co}$. The efficiency calibration curve, showed in Figure 2, was determined using a standard solution made by the National Institute of Standards and Technology (NIST) and reference materials with densities and compositions similar to the samples that will be measured after pulverization. Marinelli beakers of $500 \mathrm{~mL}$ were also used for the reference materials. Each sand sample, of approximately $1.0 \mathrm{~kg}$, was counted for $86,400 \mathrm{~s}$. All samples were measured in a low background spectrometry system inside a special counting room, shielded by water all around, over and below. The background spectrum collected from the standard solution for 24 hours is show in Figure 3. 


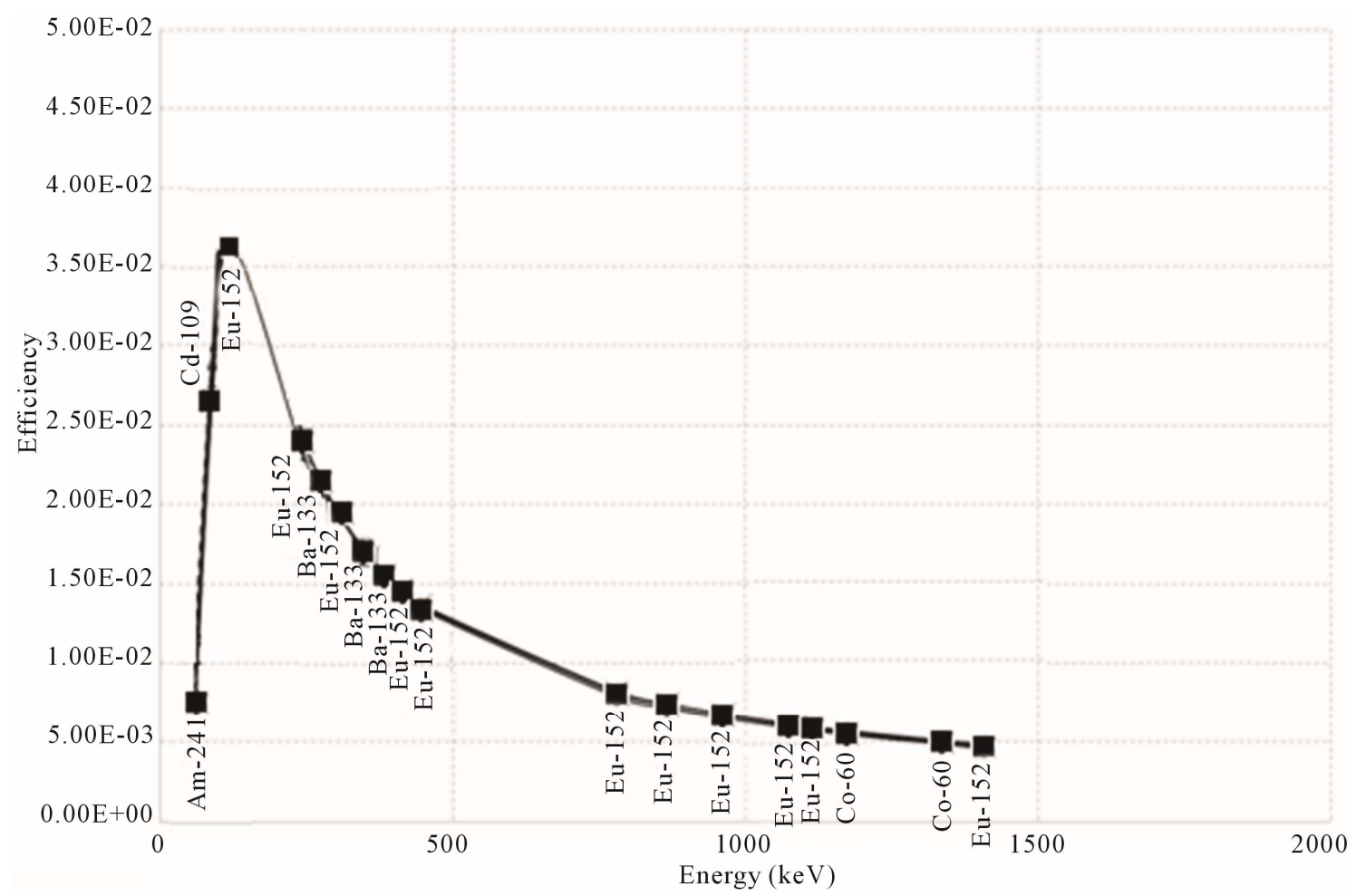

Figure 2. Absolute efficiency curve of detector HPGe from CDTN/CNEN used for analyses.

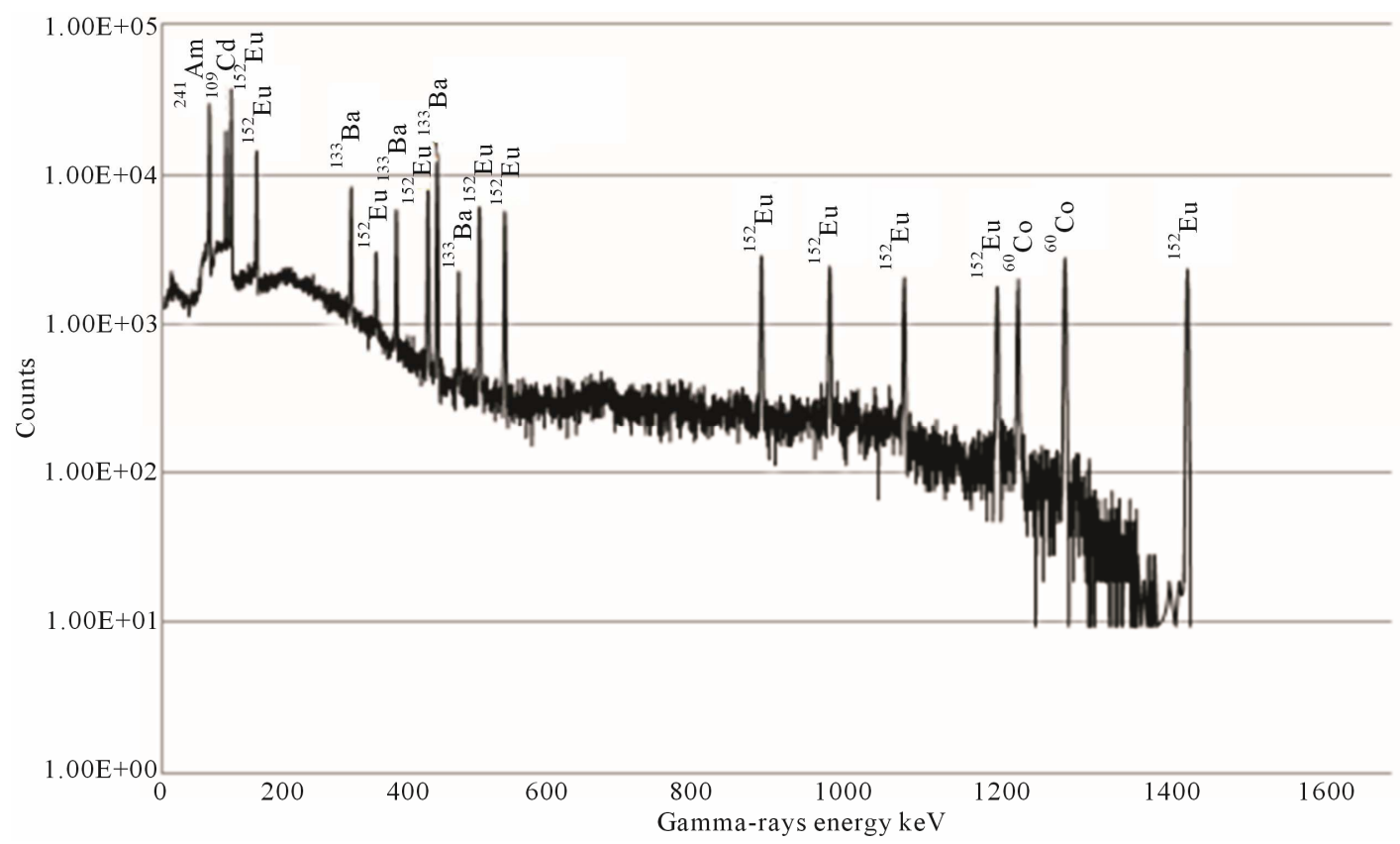

Figure 3. Background spectrum collected from the standard solution.

\subsection{Dose Calculation}

The total air absorbed dose rate $\left(\mathrm{nGy} \cdot \mathrm{h}^{-1}\right) 1 \mathrm{~m}$ above the ground due to the specific activities of ${ }^{226} \mathrm{Ra},{ }^{232} \mathrm{Th}$ and ${ }^{40} \mathrm{~K}\left(\mathrm{~Bq} \cdot \mathrm{kg}^{-1}\right)$ was calculated using the Equation (2) $[2,3]$

$$
D=0.0414 A_{\mathrm{K}}+0.461 A_{\mathrm{Ra}}+0.623 A_{\mathrm{Th}} \text {. }
$$

where $D$ is the absorbed dose rate, $A_{\mathrm{K}}, A_{\mathrm{Ra}}$ and $A_{\mathrm{Th}}$ are the activity concentrations for ${ }^{40} \mathrm{~K},{ }^{226} \mathrm{Ra}$ and ${ }^{232} \mathrm{Th}$ respectively.

To estimate the annual effective dose rates, the conversion coefficient from absorbed dose in air to effective dose $\left(0.7 \mathrm{~Sv} \cdot \mathrm{Gy}^{-1}\right)$ and outdoor occupancy factor $(0.2)$ 
proposed by [10] were used. The effective dose rate in units of $\mathrm{mSv} \cdot \mathrm{y}^{-1}$ was calculated by following Equation (3):

$$
H_{E}=D T F \text {. }
$$

where $D$ is the calculated dose rate (in $\mathrm{nGy} \cdot \mathrm{h}^{-1}$ ), $T$ is the outdoor occupancy time $(24 \mathrm{~h} \times 365.25$ days $\times 0.2=$ $\left.1753 \mathrm{~h} \cdot \mathrm{y}^{-1}\right)$, and $F$ is the conversion factor $\left(0.7 \mathrm{~Sv} \cdot \mathrm{Gy}^{-1}\right)$.

\section{Results and Discussions}

The activity concentrations of radionuclides measured in beach sand samples from Guarapari, Brazil are presented in Table 2. The naturally occurring ${ }^{226} \mathrm{Ra},{ }^{214} \mathrm{~Pb},{ }^{232} \mathrm{Th}$, ${ }^{212} \mathrm{~Pb}$ and ${ }^{40} \mathrm{~K}$ in beach sands ranged from 6.0 to 4100 , 6.0 to 3600,20 to $57,000,17$ to 47,500 and 73 to 3000 $\mathrm{Bq} \cdot \mathrm{kg}^{-1}$ respectively. All radionuclides found in these beaches sand samples are radioisotopes from the uranium, thorium and actinium decay series plus the ${ }^{40} \mathrm{~K}$. The radioisotopes ${ }^{226} \mathrm{Ra},{ }^{214} \mathrm{~Pb}$ and ${ }^{212} \mathrm{~Pb}$ are the daughter products of the ${ }^{232} \mathrm{Th}$ and ${ }^{238} \mathrm{U}$ decay series.

As shows in Table 2, determination of the activity of some ${ }^{238} \mathrm{U}$ and ${ }^{232} \mathrm{Th}$ decay products shows that radionuclides are in secular equilibrium. For example, the value for ${ }^{214} \mathrm{~Pb}$ activity (end of the ${ }^{238} \mathrm{U}$ decay chain) is equal to the ${ }^{226} \mathrm{Ra}$ activity (beginning in the decay chain). Thus, these data do not show any evidence of disequilibrium between radionuclide activities. The values of ${ }^{226} \mathrm{Ra}$, ${ }^{232} \mathrm{Th}$ and ${ }^{40} \mathrm{~K}$ in Areia Preta are higher than the range of the corresponding typical world values. However, the values of radionuclides in Praia do Morro and Setiba are lower than the range of the corresponding typical world values. The determination of ${ }^{232} \mathrm{Th} /{ }^{238} \mathrm{U}$ and ${ }^{238} \mathrm{U} /{ }^{214} \mathrm{~Pb}$ ratios is pertinent in understanding the status of secular equilibrium. If ${ }^{226} \mathrm{Ra}$, or daughters, are in secular equilibrium with ${ }^{238} \mathrm{U}$, their activity ratios and of their daughters, would be equal to unity [3]. According to [15], the analysis of the naturally occurring radioactive materials (NORM) relative abundance $(\mathrm{Th} / \mathrm{U}, \mathrm{K} / \mathrm{U}$ and $\mathrm{K} / \mathrm{Th}$ ratios) may give information on the enrichment/depletion processes as a result of the complex metamorphic history, alteration and/or weathering, which affected the investigated rocks. The ${ }^{232} \mathrm{Th} /{ }^{238} \mathrm{U}$ ratio calculated in Areia Preta was of 13.9. This value shows that there is much more ${ }^{232} \mathrm{Th}$ in samples compared to ${ }^{238} \mathrm{U}$ and it is much higher than the continental crustal average concentration of 3.82 reported by [16]. The ${ }^{40} \mathrm{~K} /{ }^{238} \mathrm{U}$ and ${ }^{40} \mathrm{~K} /{ }^{232} \mathrm{Th}$ ratios are 0.73 and 0.05 respectively, but it must be highlighted that these values are highly variables. The ${ }^{226} \mathrm{Ra} /$ ${ }^{214} \mathrm{~Pb}$ ratio calculated was of 1.1 . This ratio shows a radioactive equilibrium. Figure 4 shows an acceptably correlation between activity concentration of ${ }^{238} \mathrm{U}\left({ }^{226} \mathrm{Ra}\right)$ and ${ }^{232} \mathrm{Th}$ in the beach sand samples from Areia Preta, with a linear coefficient of 0.821 .

Table 3 shows the results of the total absorbed dose rate in the air due to gamma-ray radiation (D) and the outdoor annual effective dose rate $\left(\mathrm{H}_{\mathrm{E}}\right)$ assessment for beach sand samples.

As can be observed in Table 3, only the values of the absorbed dose rates in Areia Preta are higher than the estimate of average global primordial radiation of 59 $\mathrm{nGy} \cdot \mathrm{h}^{-1}$ and the world range $\left(10-200 \mathrm{nGy} \cdot \mathrm{h}^{-1}\right)$ [3]. The results show that the absorbed dose rates range from 18 $37,500 \mathrm{nGy} \cdot \mathrm{h}^{-1}$. The largest contribution from natural radionuclides in Areia Preta to the absorbed dose rate in air is due to ${ }^{232} \mathrm{Th}$, about $94.7 \%$ and ${ }^{226} \mathrm{Ra}$ contributes about $5 \%$. The contribution of ${ }^{40} \mathrm{~K}$ is negligible. Adopting the conversion factor that converts the absorbed dose rate in air to human effective dose equivalent, an outdoor occupancy factor which is the fraction of time spent outdoors as recommended by [3], and the mean value of absorbed dose rate obtained in the present study, the average annual outdoor effective dose is computed to be 43.00 in Areia Preta. This value is much greater than the world average value assessed by [3]. Presence of mineral monazite is the cause of the high dose. Monazite is a monoclinic mineral consisting of $70 \%$ of rare earths phosphates; thorium oxide $4 \%-6 \%$ and uranium oxide $0.15 \%-0.25 \%$ [7]. The ilmenite and monazite rich sands of Guarapari have attracted tourists because of their supposed therapeutic properties.

Table 4 shows the activity concentrations of the ${ }^{226} \mathrm{Ra}$, ${ }^{232} \mathrm{Th}$ and ${ }^{40} \mathrm{~K}$ measure in some works in Areia Preta beach from Guarapari, Brazil. The region already is well studied, therefore is an ideal local for comparison of the measures. Our measurements of ${ }^{226} \mathrm{Ra}$ and ${ }^{232} \mathrm{Th}$ from Areia Preta agree with the values measured by [2], al-

Table 2. Concentration of radionuclides in beach sand samples.

\begin{tabular}{cccccc}
\hline Radionuclides & ${ }^{226} \mathrm{Ra}$ & ${ }^{214} \mathrm{~Pb}$ & ${ }^{232} \mathrm{Th}$ & ${ }^{212} \mathrm{~Pb}$ & ${ }^{40} \mathrm{~K}$ \\
\hline Location & & $20 \pm 1$ & $\mathrm{SD}\left(\mathrm{Bq} \cdot \mathrm{kg}^{-1}\right)$ \\
Praia do Morro & $6.0 \pm 0.7$ & $6.0 \pm 0.1$ & $57,000 \pm 8684$ & $47,500 \pm 4871$ & $3000 \pm 347$ \\
Areia Preta & $4100 \pm 539$ & $3600 \pm 466$ & $25 \pm 4$ & $19 \pm 1.8$ & $73 \pm 9$ \\
Setiba & $6.0 \pm 0.4$ & $6.0 \pm 0.6$ & 30 & - & 400 \\
Typical World Value [3] & 35 & - & 30 & \\
\hline
\end{tabular}




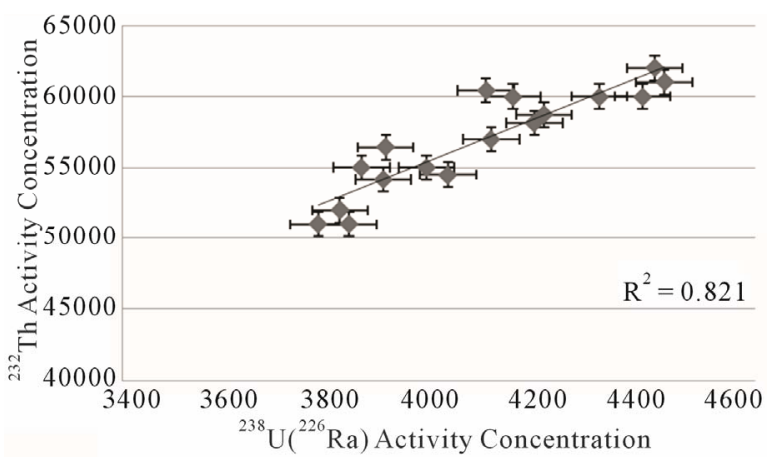

Figure 4. Correlation between activity concentrations of ${ }^{238} \mathrm{U}\left({ }^{226} \mathrm{Ra}\right)$ and ${ }^{232} \mathrm{Th}$ in beach sand samples from Areia Preta.

Table 3. Average total absorbed dose rate in air from natural radionuclides ${ }^{226} \mathrm{Ra},{ }^{232} \mathrm{Th}$ and ${ }^{40} \mathrm{~K}$ and annual effective dose in beach sands of Guarapari.

\begin{tabular}{|c|c|c|c|c|c|}
\hline \multirow{2}{*}{ Location } & \multicolumn{4}{|c|}{$\begin{array}{l}\text { Total air absorbed dose rate } \\
\mathrm{D}\left(\mathrm{nGy} \cdot \mathrm{h}^{-1}\right)\end{array}$} & \multirow[t]{2}{*}{$\begin{array}{l}\text { Annual effective } \\
\text { dose } H_{E}\left(m S v \cdot y^{-1}\right)\end{array}$} \\
\hline & ${ }^{226} \mathrm{Ra}$ & ${ }^{232} \mathrm{Th}$ & ${ }^{40} \mathrm{~K}$ & Total & \\
\hline Praia do Morro & 3.0 & 12 & 3.0 & 18 & 0.022 \\
\hline Areia Preta & 1870 & 35,500 & 130 & $37,500^{\mathrm{a}}$ & $43.00^{\mathrm{b}}$ \\
\hline Setiba & 3.0 & 16 & 3.0 & 22 & 0.023 \\
\hline
\end{tabular}

${ }^{a}$ Values higher than the world range $\left(10-200 \mathrm{nGy} \cdot \mathrm{h}^{-1}\right) ;{ }^{b}$ Values higher than worldwide average $\left(0.07 \mathrm{mSv} \cdot \mathrm{y}^{-1}\right)$. though the value of ${ }^{40} \mathrm{~K}$ is disagreement. This is expected because there are variations in environment potassium due to the variation of the organic matter. Works of more 10 years ago have lower values for ${ }^{226} \mathrm{Ra}$ and ${ }^{232} \mathrm{Th}$ than the recent works.

In Table 5, a summary of results on natural gammaray radioactivity levels derived from similar investigation conducted in some of world regions and around the Atlantic coast of Brazil is presented. Activity concentrations of ${ }^{226} \mathrm{Ra}\left({ }^{238} \mathrm{U}\right.$ daughter) from Cumuruxatiba, Bahia state, is higher than the others locals showed in the summary. According to [6], Cumuruxatiba is a place which has a large amount of monazite sand (4500 t) and indicates that the monazite deposit in Cumuruxatiba is more extensive than Guarapari. However, the highest activity concentration of ${ }^{232} \mathrm{Th}$ was found in Guarapari. On the

Table 4. Comparison of the activity concentrations of the main radionuclides gamma-ray emitter measure in some works in Areia Preta beach, Guarapari, Brazil.

\begin{tabular}{cccc}
\hline References & ${ }^{226} \mathrm{Ra}\left(\mathrm{Bq} \cdot \mathrm{kg}^{-1}\right)$ & ${ }^{232} \mathrm{Th}\left(\mathrm{Bq} \cdot \mathrm{kg}^{-1}\right)$ & ${ }^{40} \mathrm{~K}\left(\mathrm{~Bq} \cdot \mathrm{kg}^{-1}\right)$ \\
\hline$[7]$ & 2412 & 36,620 & 172 \\
{$[8]$} & 2250 & 27,500 & - \\
{$[2]$} & 4043 & 55,537 & 63 \\
Present study & 4100 & 57,000 & 3000 \\
\hline
\end{tabular}

Table 5. Summary of activity concentrations and dose rates of natural radioisotopes in soil and sand samples in some of the world regions; (-) not determined.

\begin{tabular}{|c|c|c|c|c|c|c|}
\hline Region/Country & ${ }^{226} \mathrm{Ra}\left(\mathrm{Bq} \cdot \mathrm{kg}^{-1}\right)^{2}$ & ${ }^{232} \mathrm{Th}\left(\mathrm{Bq} \cdot \mathrm{kg}^{-1}\right)$ & ${ }^{40} \mathrm{~K}\left(\mathrm{~Bq} \cdot \mathrm{kg}^{-1}\right)$ & $\begin{array}{l}\text { Total air absorbed dose } \\
\text { rate } \mathrm{D}\left(\mathrm{nGy} \cdot \mathrm{h}^{-1}\right)\end{array}$ & $\begin{array}{c}\text { Annual effective dose } \\
\mathrm{H}_{\mathrm{E}}\left(\mathrm{mSv} \cdot \mathrm{y}^{-1}\right)\end{array}$ & References \\
\hline & mean & mean & mean & & & \\
\hline Manisa/Turkey & - & 27 & 340 & 54 & - & [1] \\
\hline Persian Gulf/Iran & 35 & 26 & 395 & 37 & - & {$[17]$} \\
\hline Safaga/Egypt & 25.3 & 21.4 & 618 & 50.9 & - & {$[18]$} \\
\hline Bushehr/Iran & 35 & 17 & 285 & 30 & - & {$[19]$} \\
\hline Preta Beach/Brazil & - & 239 & 110 & 125 & 0.15 & [9] \\
\hline Xianyang/China & 31.1 & 44.9 & 776 & 73.9 & 0.091 & {$[20]$} \\
\hline Baoji/China & 22.1 & 39 & 859 & 69.6 & 0.085 & {$[21]$} \\
\hline Rizhao/China & 12 & 15.2 & 1079 & 59.8 & 0.073 & {$[22]$} \\
\hline Meaipe/Brazil & 1001 & 6422 & 127 & - & - & [2] \\
\hline Orissa/India & - & 2825 & 180 & 1925 & 2.36 & {$[5]$} \\
\hline Porto Seguro/Brazil & $20^{*}$ & $30^{*}$ & $20^{*}$ & 21 & 0.03 & [6] \\
\hline Trancoso/Brazil & $90^{*}$ & $300^{*}$ & $40^{*}$ & 130 & 0.16 & [6] \\
\hline Prado/Brazil & $110^{*}$ & $30^{*}$ & $60^{*}$ & 40 & 0.04 & [6] \\
\hline Alcobaça/Brazil & $510^{*}$ & $400^{*}$ & $180^{*}$ & 330 & 0.40 & [6] \\
\hline Cumuruxatiba (non-black sand)/Brazil & $230^{*}$ & $1435^{*}$ & $73^{*}$ & 903 & 1.11 & {$[6]$} \\
\hline Cumuruxatiba (black sand)/Brazil & $8320^{*}$ & $18,450^{*}$ & $3110^{*}$ & 4450 & 17.70 & [6] \\
\hline Areia Preta/Guarapari, Brazil & 4100 & 57,000 & 3000 & 37,500 & 43.00 & Present Study \\
\hline
\end{tabular}

*Maximum value. 
other hand, ${ }^{238} \mathrm{U}$ concentration is highest in Cumuruxatiba. The activity concentration of ${ }^{40} \mathrm{~K}$ from Cumuruxatiba is higher than the others regions and slightly higher than Guarapari. Values of total air absorbed dose rate (D) and annual effective dose $\left(\mathrm{H}_{\mathrm{E}}\right)$ from Guarapari are very higher than the values from Orissa, India [5] and Cumuruxatiba, Brazil [6]. Orissa and Cumuruxatiba are HBRAs.

\section{Conclusion}

The exposure level due to monazite sand radiation in Areia Preta beach, Guarapari, is high. The activity concentration of ${ }^{232} \mathrm{Th}$ in Areia Preta is higher than others beaches in world studied and others regions from coast Brazilian such as Cumuruxatiba and Porto Seguro although the activity concentration of ${ }^{238} \mathrm{U}$ is lower than Cumuruxatiba. The values of the absorbed dose rate in air and outdoor annual effective dose rate in Areia Preta beach are higher than the world averages due the content of ${ }^{232} \mathrm{Th}$. Areia Preta has the highest background found in beaches in world and beside Cumuruxatiba are highest background from coast Brazilian with values much higher than worldwide average. The measured values in Areia Preta agree with values found by others studies which validate our methodology.

\section{Acknowledgements}

The authors thank to the Centro de Desenvolvimento da Tecnologia Nuclear-CDTN/CNEN, where this study was carried out. The authors also are grateful to FAPEMIG, CNPq and CAPES for financial assistance.

\section{REFERENCES}

[1] F. S. Ereeş, S. Aközcan, Y. Parlak and S. Çam, "Assessment of Dose Rates around Manisa (Turkey)," Radiation Measurements, Vol. 41, No. 5, 2006, pp. 598-601. doi:10.1016/i.radmeas.2005.11.004

[2] R. Veiga, N. Sanches, R. M. Anjos, K. Macario, J. Bastos, M. Iguatemy, J. G. Aguiar, A. M. A. Santos, B. Mosquera, C. Carvalho, M. Baptista Filho and N. K. Umisedo, "Measurement of Natural Radioactivity in Brazilian Beach Sands," Radiation Measurements, Vol. 41, No. 2, 2006, pp. 189-196. doi:10.1016/j.radmeas.2005.05.001

[3] United Nations Scientific Committee on the Effects of Atomic Radiation, "Sources and Effects of Ionizing Radiation," Report to General Assembly, with Scientific Annexes, United Nations, New York, 2000.

[4] M. Ghiassi-nejad, S. M. J. Mortazavi, J. R. Cameron, A. Niroomand-rad and P. A. Karam, "Very High Background Radiation Areas of Ramsar, Iran: Preliminary Biological Studies," Health Physics, Vol. 82, No. 1, 2002, pp. 87-93. doi:10.1097/00004032-200201000-00011

[5] A. K. Mohanty, D. Sengupta, S. K. Das, V. Vijayan and S. K. Saha, "Natural Radioactivity in the Newly Discovered High Background Radiation Area on the Eastern Coast of
Orissa, India," Radiation Measurements, Vol. 38, No. 2, 2004, pp. 153-165. doi:10.1016/j.radmeas.2003.08.003

[6] D. C. Vasconcelos, C. Pereira, A. H. Oliveira, T. O. Santos, Z. Rocha and M. A. B. C. Menezes, "Determination of Natural Radioactivity in Beach sand in the Extreme South of Bahia, Brazil, Using Gamma Spectrometry," Radiation Protection and Environment, Vol. 34, No. 3, 2012, pp. 178-184.

[7] A. Malarica, C. N. Luce, R. Sogni, L. Achilli and S. Fabbri, "Naturally Occurring Radionuclides in the Monazite Sands of Guarapari and Meaipe (Brazil)," Proceedings of the La Radioattività Ambientale nel Nuovo assetto Istituzionale Piancenza, Bologna and Ravenna, 3 November 1994, pp. 225-230.

[8] N. Fujinami, T. Koga and H. Morishima, "External Exposure from Terrestrial Radiation at Guarapari and Meaipe in Brazil," Proceedings of the 10th International Congress of the International Radiation Protection Association, Hiroshima, 14-19 May 2000, pp. 1-19.

[9] A. C. Freitas and A. S. Alencar, "Gamma Dose Rates and Distribution of Natural Radionuclides in Sand BeachesIlha Grande, Southeastern Brazil," Journal of Environmental Radioactivity, Vol. 75, No. 2, 2004, pp. 211-223. doi:10.1016/j.jenvrad.2004.01.002

[10] G. F. Knoll, "Radiation Detection and Measurement," 4th Edition, John Wiley \& Sons Ltd., New York, 1989.

[11] CPRM, "Rio de Janeiro Project. Geological Service of Brazil," 2012. http://www.cprm.gov.br

[12] Google Maps, 2012. http://maps.google.com.br/maps

[13] “The Berkeley Laboratory Isotopes Project's: Exploring the Table of Isotopes," 2011. http://ie.lbl.gov/education/isotopes.htm

[14] “Table of Nuclides: Nuclear Data Services," 2011. http://www-nds.iaea.org/relnsd/vcharthtml/VChartHTML .html

[15] P. Chiozzi, V. Pasquale and M. Verdoya, "Naturally Occurring Radioactivity at the Alps-Apennines Transition," Radiation Measurements, Vol. 35, No. 2, 2002, pp. 147154. doi:10.1016/S1350-4487(01)00288-8

[16] National Council on Radiation Protection and Measurements (NCRP), "Exposure of the Population in the United States and Canada from Natural Background Radiation," NCRP Report No. 94, Maryland, 2011

[17] M. R. Abdi, H. Faghihian, M. Kamali, M. Mostajaboddavati and A. Hasanzadeh, "Distribution of Natural Radionuclides on Coasts of Bushehr, Persian Gulf, Iran," Iranian Journal of Science \& Technology, Transaction A, Vol. 30, No. A3, 2006, pp. 259-268.

[18] A. M. El-Arabi, "Natural Radioactivity in Sand Used in Thermal Therapy at the Red Sea Coast," Journal of Environmental Radioactivity, Vol. 81, No. 1, 2005, pp. 1119. doi:10.1016/j.jenvrad.2004.11.002

[19] M. R. Abdi, M. Kamali and Vaezifar, "Distribution of Radioactive Pollution of ${ }^{238} \mathrm{U},{ }^{232} \mathrm{Th},{ }^{40} \mathrm{~K}$ and ${ }^{137} \mathrm{Cs}$ in Northwestern Coasts of Persian Gulf, Iran," Marine Pollution Bulletin, Vol. 56, No. 4, 2008, pp. 751-757. doi:10.1016/j.marpolbul.2007.12.010 
[20] X. Lu, X. Zhang and F. Wang, "Natural Radioactivity in Sediment of Wei River, China," Environmental Geology, Vol. 53, No. 7, 2008, pp. 1475-1481. doi:10.1007/s00254-007-0756-0

[21] X. Lu and X. Zhang, "Measurement of Natural Radiactivity in Sand Samples Collected from the Baoji Weihe Sands Park, China," Environmental Geolology, Vol. 50,
No. 7, 2006, pp. 977-982. doi:10.1007/s00254-006-0266-5

[22] X. Lu and X. Zhang, "Measurement of Natural Radioactivity in Beach Sands from Rizhao Bathing Beach, China," Radiation Protection Dosimetry, Vol. 130, No. 3, 2008, pp. 385-388. doi:10.1093/rpd/nen053 